Journal of Telenursing (JOTING)

Volume 1, Nomor 1, Juni 2019

e-ISSN : 2684-8988

p-ISSN : 2684-8996

DOI: https://doi.org/10.31539/joting.v1i1.492

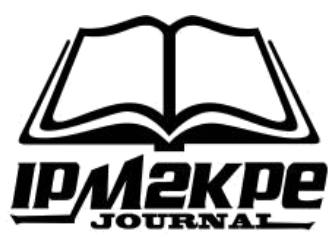

\title{
EFEKTIVITAS PERBANDINGAN BUERGER ALLEN EXERCISE DAN SENAM KAKI TERHADAP NILAI ABI PADA PENDERITA DM TIPE II
}

\author{
Awinda Sari ${ }^{1}$, Anwar Wardy W², Yani Sofiani ${ }^{3}$ \\ Universitas Muhammadiyah Jakarta ${ }^{1,2,3}$ \\ awinda_sari@ymail.com ${ }^{1}$
}

\begin{abstract}
ABSTRAK
Tujuan penelitian ini yaitu didapatkan hasil perbandingan efektivitas Buerger Allen Exercise dan senam kaki terhadap nilai Ankle Brachial Index (ABI) pada penderita Diabetes Mellitus Tipe II. Metode penelitian ini adalah metode kuantitatif dengan Desain penelitian Quasi Experiment pre dan post test two groups. Hasil penelitian diperoleh ada perbedaan yang signifikan nilai Ankle Brachial Index (ABI) sebelum dan sesudah diberikan perlakuan Buerger Allen Exercise dan senam kaki yaitu $p<0,05$ dengan perbedaan selisih rata-rata peningkatan nilai ABI pada kelompok Buerger Allen Exercise sebesar 0,0820 sedangkan pada kelompok senam kaki selisih rata-rata peningkatan nilai ABI sebesar 0,0726. Simpulan, buerger allen exercise lebih efektif daripada senam kaki dalam meningkatkan nilai Ankle Brachial Index (ABI).
\end{abstract}

Kata Kunci : Ankle Brachial Index, Buerger Allen Exercise, Diabetes Mellitus Tipe II, Senam Kaki

\section{ABSTRACT}

The purpose of this study is to obtain a comparison of the effectiveness of the Buerger Allen Exercise and foot exercises on the value of the Ankle Brachial Index (ABI) in patients with Type II Diabetes Mellitus. This research method is a quantitative method with a research design Quasi Experiment pre and post test two groups. The results showed that there was a significant difference in the value of the Ankle Brachial Index (ABI) before and after being given Buerger Allen Exercise and foot exercises, namely $p$ $<0.05$ with the difference in the average difference in the increase in ABI values in the Buerger Allen Exercise group of 0.0820, while in the leg exercise group, the difference in the average increase in the ABI value was 0.0726. In conclusion, Buerger Allen exercise is more effective than leg exercises in increasing the value of the Ankle Brachial Index (ABI).

Keywords: Ankle Brachial Index, Buerger Allen Exercise, Type II Diabetes Mellitus, Foot Exercise

\section{PENDAHULUAN}

Diabetes mellitus adalah kelainan metabolisme karbohidrat, lemak, dan protein yang di tandai dengan meningkatnya kadar glukosa di dalam darah (hiperglikemia). Tingginya kadar glukosa dalam darah disebabkan karena adanya kelainan pengeluaran insulin, kelainan kerja insulin di dalam tubuh, atau kedua-duanya (Perkeni, 2015). Insulin adalah hormon yang berfungsi untuk meregulasi kadar glukosa dalam darah. 
Peningkatan kadar glukosa dalam darah atau hiperglikemia sendiri merupakan gejala umum yang terjadi pada penderita diabetes dan seringkali mengakibatkan komplikasi seperti kerusakan-kerusakan yang cukup serius pada tubuh, terutama pada pembuluh darah ke otak, jantung, perifer, sel saraf, mata, dan ginjal sel saraf dan pembuluh darah (Black \& Hawks, 2014).

International Diabetes Federation mengungkapkan bahwa prevalensi diabetes di dunia pada tahun 2015 sebanyak 415 juta jiwa, dan tahun 2040 jumlah tersebut diperkirakan akan meningkat menjadi 642 juta jiwa. Jumlah penderita diabetes di Asia Tenggara sebanyak 87 juta jiwa. Meningkatnya prevalensi DM di negara berkembang salah satunya disebabkan karena perubahan gaya hidup dan Indonesia adalah salah satu negara berkembang dengan prevalensi diabetes yang cukup tinggi. Prevalensi penderita diabetes di Indonesia tahun 2015 sebesar 10 juta jiwa dan Indonesia menempati urutan ke 7 di dunia setelah Cina (109,6 juta jiwa), India ( 69,2 juta jiwa), Amerika Serikat ( 29,3 juta jiwa), Brazil (14,3 juta jiwa), Rusia (12,3 juta jiwa), dan Meksiko ( 11,5 juta jiwa) (IDF, 2015).

Diabetes mellitus menempati urutan keempat dari sepuluh penyakit tidak menular (PTM) di Indonesia dengan prevalensi 1,5\%. Penyakit Diabetes Mellitus menyebar di seluruh provinsi di Indonesia salah satunya provinsi DKI Jakarta. Prevalensi penderita yang terdiagnosa diabetes mellitus di DKI Jakarta dengan usia $\geq 15$ tahun sebesar 2,5\% dengan jumlah perkiraan penderita sebanyak 190.232 jiwa (Riskesdas, 2013). Menurut International Diabetes Federation, diabetes mellitus Tipe II merupakan diabetes yang paling banyak ditemui, yaitu sekitar 90-95\% dari seluruh tipe diabetes yang ada (IDF, 2015).

Diabetes mellitus Tipe II disebut diabetes mellitus yang tidak tergantung insulin dan terjadi akibat penurunan sensitivitas terhadap insulin (resistensi insulin) dan gangguan sekresi insulin (Black \& Hawks, 2014). Hal tersebut disebabkan karena turunnya kemampuan insulin untuk merangsang pengambilan glukosa oleh jaringan perifer. Sel tidak mampu mengimbangi resistensi insulin sepenuhnya artinya terjadi defisiensi insulin relative, atau dapat dikatakan sel pankreas mengalami desentisisasi terhadap glukosa akibatnya terjadilah penumpukan glukosa di dalam darah (hiperglikemia) (Guyton, 2012).

Kondisi hiperglikemia yang tidak di kelola dengan baik dalam waktu yang cukup lama membuat penderita Diabetes Mellitus sangat rentan terhadap komplikasi kronis vaskuler yaitu gangguan aliran pembuluh darah ke kaki. Hiperglikemia akan mempengaruhi fungsi platelet darah yang dapat menyebabkan pembekuan darah, sehingga penderita DM akan berisiko mengalami penyakit arteri perifer yang biasanya sering menyerang ekstremitas bawah yaitu organ kaki (Kohlman \& Trigoboff, 2013).

Penyakit arteri perifer merupakan penyempitan pembuluh darah arteri perifer yang disebabkan karena aterosklerosis sehingga aliran darah ke ekstremitas menjadi berkurang (Setiati et al., 2015). Penurunan suplai darah ke ekstremitas atau gangguan sirkulasi perifer ekstremitas bawah merupakan salah satu penyebab terjadinya ulkus diabetikum pada kaki (Rebolledo et al., 2011). Penyakit arteri perifer ekstremitas bawah merupakan penyebab ulkus diabetikum yang paling sering ditemukan. Sekitar $15 \%$ penderita DM akan mengalami ulkus kaki diabetes dalam masa hidupnya (Leone et al., 2012). Ulkus inilah yang memicu terjadinya infeksi dan amputasi, 50\% ulkus akan terinfeksi dan 25\% membutuhkan tindakan amputasi (Singh et al., 2013). Ulkus diabetikum merupakan komplikasi DM yang paling sering ditemukan dan mengancam kehidupan. Ulkus diabetikum adalah penyebab paling umum amputasi kaki 
nontraumatik diseluruh dunia. Menurut Setiati et al., (2015) ada beberapa faktor lain yang mempengaruhi vaskularisasi perifer diantaranya adalah usia, merokok, hipertensi, dislipidemia serta lama menderita DM.

Pemeriksaan penunjang yang paling sederhana yang dapat dilakukan untuk mendeteksi gangguan sirkulasi perifer adalah dengan menilai nilai Ankle Brachial Index (ABI). Ankle brachial index (ABI) merupakan pemeriksaan non invasive pembuluh darah dan merupakan sebuah metode sederhana yang berfungsi untuk mendeteksi adanya tanda dan gejala gangguan pembuluh darah perifer seperti iskemia (AHA, 2012). Nilai ABI > 1.0 dikatakan baik atau normal dan apabila $<0.9$ dikatakan beresiko terjadi gangguan sirkulasi perifer oleh karena itu tindakan untuk mendeteksi gangguan sirkulasi perifer yang tepat untuk pasien DM adalah dengan mengukur ABI (Williams \& Wilkins, 2012). Kasus amputasi akibat DM sekitar 50\% dapat dihindari melalui tindakan preventif (Smeltzer \& Bare, 2008). Pencegahan kaki diabetes dapat dilakukan dengan cara modifikasi gaya hidup, mengontrol gula darah dan tekanan darah, manajemen lipid, berhenti merokok, serta melakukan perawatan kaki (Iraj et al., 2013).

Menurut penelitian yang dilakukan oleh Sihombing et al., (2012) menyimpulkan bahwa perawatan kaki secara teratur dapat mengurangi penyakit kaki diabetik sebesar 50-60\% yang mempengaruhi kualitas hidup. Perawatan kaki merupakan pencegahan primer agar tidak terjadinya ulkus diabetikum seperti membersihkan kaki, memakai kaos kaki, pemilihan alas kaki yang tepat, serta melakukan latihan kaki (Aalaa et al., 2012). Latihan kaki adalah salah satu latihan fisik untuk perawatan kaki yang dapat diberikan kepada penderita Diabetes Mellitus untuk mencegah terjadinya penyakit arteri perifer dengan tujuan meningkatkan sirkulasi perifer kaki. Latihan kaki yang dapat dilakukan adalah buerger allen exercise dan senam kaki.

Buerger allen exercise adalah sistem latihan untuk insufisiensi arteri tungkai bawah dengan menggunakan perubahan gravitasi pada posisi yang diterapkan dan muscle pump yang terdiri dari dorsofleksi dan plantarfleksi melalui gerakan aktif dari pergelangan kaki untuk kelancaran otot pembuluh darah. Muscle pump dengan dorsofleksi dan plantarfleksi dapat merangsang endotel untuk mengeluarkan atau melepaskan nitrit oksida sehingga akan memberikan sinyal ke otot polos vaskular untuk relaksasi. Pada saat sel otot-otot polos relaksasi maka pembuluh darah akan vasodilatasi sehingga aliran darah ke perifer kaki menjadi lancar (Purnawarman \& Nurkhalis, 2014). Sedangkan perubahan postural (gravitasi pada posisi yang diterapkan) pada buerger allen exercise akan membantu mengosongkan dan mengisi kolom darah secara bergantian sehingga dapat meningkatkan transportasi darah melalui pembuluh darah. Selain buerger allen exercise, senam kaki juga merupakan latihan kaki untuk mencegah terjadinya penyakit arteri perifer (Sherwood, 2016).

Penelitian Abishal (2016) menyatakan bahwa Buerger Allen Exercise diberikan selama $5 \mathrm{kali} / \mathrm{hari}$ dalam kurun waktu 5 hari menunjukkan hasil terjadi peningkatan perfusi ekstremitas bawah yaitu nilai ABI. Selain itu Priya (2016) melakukan penelitian Buerger Allen Exercise diberikan selama 2 kali/hari dengan interval 6 jam dalam kurun waktu 5 hari menunjukkan hasil bahwa terjadi peningkatan nilai ABI.

Senam kaki adalah latihan fisik kaki yang dilakukan dengan menggerakkan seluruh sendi kaki dan pergelangan kaki yang disesuaikan dengan kemampuan pasien. Latihan atau gerakan-gerakan yang dilakukan oleh kedua kaki secara bergantian atau bersamaan bermanfaat untuk melancarkan peredaran darah kaki, serta otot-otot di tungkai bawah menjadi lentur dan kuat, terutama pada kedua pergelangan kaki dan jarijari kaki (Damayanti, 2015). Latihan kaki dalam bentuk senam kaki dengan 
menggerakkan otot-otot secara aktif akan merangsang endotel pembuluh darah untuk mengeluarkan atau melepaskan nitrit oksida. Nitrit oksida akan menstimulasi soluble guanilate cyclase (SGC) yang menyebabkan peningkatan sintesa siklik GMP dari guanosin triphosphate (GTP) (Isral, 2014). Peningkatan siklik GMP ini akan menyebabkan otot polos pembuluh darah tersebut relaksasi. Pada saat sel otot-otot polos relaksasi maka pembuluh darah akan vasodilatasi sehingga aliran darah ke perifer kaki menjadi lancar (Purnawarman \& Nurkholis, 2014).

Menurut penelitian yang dilakukan oleh Mangiwa et al., (2017) bahwa senam kaki yang dilakukan dapat meningkatkan sirkulasi kaki. Hasil dari penelitian tersebut menunjukkan perbedaan yang signifikan antara nilai ABI sebelum diberikan senam kaki yaitu sebanyak 15 responden (50\%) dengan setelah diberikan senam kaki sebanyak 29 responden (96,7\%). Penelitian Wahyuni (2013) menyimpulkan bahwa senam kaki dapat meningkatkan nilai ABI, senam kaki diberikan selama 2 kali/ hari dalam kurun waktu 6 hari menunjukkan hasil perubahan ABI sebelum perlakuan ABI normal sebanyak 7 responden $(46,7 \%)$ sedangkan sesudah perlakuan ABI normal menjadi 11 responden $(73,3 \%)$.

\section{METODE PENELITIAN}

Penelitian ini menggunakan quasi-experimental design dengan pendekatan pretest-posttest two groups design. Jumlah sampel yang digunakan adalah 15 responden yang masuk dalam kelompok intervensi A (diberikan perlakuan Buerger Allen Exercise) dan 15 responden yang masuk dalam kelompok intervensi B (diberikan perlakuan senam kaki). Tempat penelitian dilakukan di ruang rawat inap Rumah Sakit Islam Jakarta Pondok Kopi dan dilaksanakan pada tanggal 23 April - 14 Mei 2018.

Alat pengumpulan data pada penelitian ini berupa kuesioner (meliputi karakteristik responden seperti umur, jenis kelamin, riwayat merokok, riwayat hipertensi, riwayat kolesterol, dan lama menderita DM), Instrumen Pengukuran Ankle Brachial Index (ABI) yaitu vascular doppler ultrasound probe dan sphygnomanometer, SOP pengukuran Ankle Brachial Index (ABI), SOP pelaksanaan buerger allen exercise, SOP pelaksanaan senam kaki, serta lembar observasi. Selanjutnya dari data yang telah terkumpul dilakukan pengolahan data yang dilakukan melalui tahap editing (pemeriksaan kembali), coding (pengkodean), entry data (pemasukan data) dan cleaning (pembersihan data).

Analisis univariat dilakukan untuk mendiskripsikan semua variabel yang diteliti. Adapun variabel yang dianalisis dengan univariat adalah karakteristik dan variabel confounding seperti usia, lama menderita DM, dan variabel dependen nilai Ankle Brachial Index (ABI) yang merupakan data numerik dengan menghitung mean, standar deviasi, nilai maksimum dan minimum dengan confidence interval 95\%. Untuk karakteristik jenis kelamin, riwayat merokok, riwayat hipertensi, dan riwayat kolesterol, dengan menghitung frekuensi dan presentase.

Analisis bivariat dilakukan untuk membuktikan hipotesis penelitian yaitu dengan melihat perbedaan nilai Ankle Brachial Index (ABI) setelah dilakukan latihan pada kelompok intervensi buerger allen exercise dan nilai ABI setelah dilakukan latihan pada kelompok intervensi senam kaki. Uji statistik bivariat yang digunakan pada penelitian ini menggunakan uji beda dua mean dependen (paired sample $T$-test), dengan nilai $\alpha=$ 0,05 . 


\section{HASIL PENELITIAN}

Tabel 1

Distribusi Responden Berdasarkan Usia, Jenis Kelamin, Riwayat Merokok, Riwayat Hipertensi, Riwayat Kolesterol, dan Lama Menderita DM pada Penderita DM (n=30)

\begin{tabular}{|c|c|c|c|c|c|c|c|}
\hline No & Variabel & Kategorik & (f) & $(\%)$ & Mean & SD & Min -Max \\
\hline 1 & Usia & & & & & & \\
\hline \multirow{4}{*}{2} & $\begin{array}{l}\text { Buerger Allen } \\
\text { Exercise }\end{array}$ & - & 15 & 100 & 58,27 & 7,977 & $45-71$ \\
\hline & $\begin{array}{l}\text { Senam Kaki } \\
\text { Lama Menderit }\end{array}$ & $\mathrm{DM}$ & 15 & 100 & 60,27 & 5,325 & $48-70$ \\
\hline & $\begin{array}{l}\text { Buerger Allen } \\
\text { Exercise }\end{array}$ & - & 15 & 100 & 9,13 & 5,083 & $2-20$ \\
\hline & Senam Kaki & - & 15 & 100 & 9,27 & 5,535 & $2-20$ \\
\hline \multirow[t]{5}{*}{3} & Jenis Kelamin & & & & & & \\
\hline & Buerger Allen & Laki-laki & 8 & 53,3 & - & - & - \\
\hline & Exercise & Perempuan & 7 & 46,7 & & & \\
\hline & Senam Kaki & Laki-laki & 8 & 53,3 & & & \\
\hline & & Perempuan & 7 & 46,7 & - & - & - \\
\hline \multirow[t]{5}{*}{4} & Riwayat Merok & & & & & & \\
\hline & Buerger Allen & $\mathrm{Ya}$ & 5 & 33,3 & - & - & - \\
\hline & Exercise & Tidak & 10 & 66,7 & & & \\
\hline & Senam Kaki & $\mathrm{Ya}$ & 8 & 53,3 & & & \\
\hline & & Tidak & 7 & 46,7 & - & - & - \\
\hline \multirow[t]{6}{*}{5} & Riwayat Hiperte & & & & & & \\
\hline & Buerger Allen & $\mathrm{Ya}$ & 9 & 60 & - & - & - \\
\hline & Exercise & Tidak & 6 & 40 & & & \\
\hline & Senam Kaki & & & & & & \\
\hline & & $\mathrm{Ya}$ & 12 & 80 & - & - & - \\
\hline & & Tidak & 3 & 20 & & & \\
\hline \multirow[t]{5}{*}{6} & Riwayat Kolest & & & & & & \\
\hline & Buerger Allen & $\mathrm{Ya}$ & 6 & 40 & - & - & - \\
\hline & Exercise & Tidak & 9 & 60 & & & \\
\hline & Senam Kaki & $\mathrm{Ya}$ & 6 & 40 & & & \\
\hline & & Tidak & 9 & 60 & - & - & - \\
\hline
\end{tabular}

Sumber : Data Penelitian 2018

Berdasarkan tabel 1 menunjukkan hasil bahwa responden yang memiliki rata-rata usia tertinggi adalah kelompok senam kaki yaitu 60,27 ( $\mathrm{SD}=5,325)$ dengan usia responden minimal 45 tahun dan maksimal 71 tahun. Jenis kelamin responden terbanyak pada kelompok buerger allen exercise dan senam kaki adalah laki-laki sebanyak $8(53,3 \%)$. Untuk riwayat merokok terbanyak adalah kelompok senam kaki yaitu sebanyak 8 (53,3\%). Riwayat hipertensi responden terbanyak adalah kelompok senam kaki sebanyak 12 (80\%). Sedangkan untuk riwayat kolesterol pada kelompok buerger allen exercise dan senam kaki terbanyak adalah tidak memiliki riwayat kolesterol sebanyak 9 (60\%). Responden yang memiliki rata-rata lama menderita DM 
tertinggi adalah kelompok senam kaki yaitu 9, $27(\mathrm{SD}=5,535)$, dengan lama menderita DM minimal 2 tahun dan maksimal 20 tahun

Tabel. 2

Distribusi Rata-Rata Ankle Brachial Index (ABI) Sebelum dan Sesudah Perlakuan pada Kelompok Buerger Allen Exercise dan Senam Kaki $(\mathrm{n}=30)$

\begin{tabular}{cccccc}
\hline \multicolumn{5}{c}{ Ankle Brachial Index (ABI) } \\
\hline Kelompok & Pengukuran & Mean & SD & Min-Max & 95 \% CI \\
\hline $\begin{array}{c}\text { Buerger } \\
\text { Allen }\end{array}$ & Pre Test & 0,9813 & 0,14643 & $0,71-1,27$ & $0,9100-1,0573$ \\
Exercise & Post Test & 1,0633 & 0,08033 & $0,92-1,18$ & $1,0247-1,1033$ \\
\hline Senam Kaki & Pre Test & 0,9633 & 0,12122 & $0,71-1,10$ & $0,9027-1,0247$ \\
& & & & & \\
& Post Test & 1,0360 & 0,10084 & $0,84-1,18$ & $0,9847-1,0853$ \\
\hline \multicolumn{2}{l}{ Sumber : Data Penelitian 2018 }
\end{tabular}

Berdasarkan tabel 2 menunjukkan hasil bahwa pada kelompok buerger allen exercise didapatkan rata-rata nilai $\mathrm{ABI}$ sebelum perlakuan yaitu $0,9813(\mathrm{SD}=0,14643)$. Dengan tingkat kepercayaan 95\% rata-rata nilai ABI diyakini antara 0,9100-1,0573. Sedangkan rata-rata nilai $\mathrm{ABI}$ sesudah perlakuan yaitu 1,0633 ( $\mathrm{SD}=0,08033)$, dengan tingkat kepercayaan 95\% rata-rata nilai ABI diyakini antara 1,0247-1,1033. Pada kelompok senam kaki didapatkan rata-rata nilai $\mathrm{ABI}$ sebelum perlakuan yaitu 0,9633 $(\mathrm{SD}=0,12122)$, Dengan tingkat kepercayaan $95 \%$ rata-rata nilai $\mathrm{ABI}$ diyakini antara 0,9027-1,0247. Sedangkan rata-rata nilai ABI sesudah perlakuan yaitu 1,0360 $(\mathrm{SD}=0,10084)$, dengan tingkat kepercayaan $95 \%$ rata-rata nilai $\mathrm{ABI}$ diyakini antara 0,9847-1,0853.

Tabel. 3

Perbedaan Nilai Ankle Brachial Index (ABI) Sebelum dan Sesudah Perlakuan pada Kelompok Buerger Allen Exercise

\begin{tabular}{lccccccc}
\hline Kelompok & $\begin{array}{c}\text { Pengukur } \\
\text { an }\end{array}$ & $\mathrm{n}$ & Mean & $\begin{array}{c}\text { Mean } \\
\text { Difference }\end{array}$ & SD & SE & $\begin{array}{c}\text { P- } \\
\text { value }\end{array}$ \\
\hline $\begin{array}{l}\text { Buerger } \\
\begin{array}{l}\text { Allen } \\
\text { Pre Test }\end{array}\end{array}$ & 15 & 0,9813 & 0,0820 & 0,14643 & 0,03781 & \\
Pxercise & Post Test & 15 & 1,0633 & & 0,08033 & 0,02074 &
\end{tabular}

Sumber : Data Penelitian 2018

Berdasarkan tabel 3 didapatkan hasil bahwa pada kelompok buerger allen exercise rata-rata nilai $\mathrm{ABI}$ sebelum perlakuan adalah 0,9813 $(\mathrm{SD}=0,14643)$. Sedangkan rata-rata nilai $\mathrm{ABI}$ sesudah perlakuan adalah 1,0633 (SD=0,08033). Hasil statistik uji $\mathrm{T}$ berpasangan (paired t-test) untuk nilai Ankle Brachial index (ABI) didapatkan nilai $p=0,008(p<0,05)$ maka dapat ditarik kesimpulan a) secara statistik nilai ABI sebelum diberikan perlakuan buerger allen exercise berbeda dengan nilai ABI sesudah diberikan buerger allen exercise ; b) ada perbedaan yang signifikan antara nilai ABI sebelum dan sesudah diberikan perlakuan buerger allen exercise. 
Tabel 4

Perbedaan Nilai Ankle Brachial Index (ABI) Sebelum dan Sesudah Perlakuan pada Kelompok Senam Kaki

\begin{tabular}{cccccccc}
\hline Kelompok & Pengukuran & $\mathrm{n}$ & Mean & $\begin{array}{c}\text { Mean } \\
\text { Difference }\end{array}$ & SD & SE & $\begin{array}{c}\text { P- } \\
\text { value }\end{array}$ \\
\hline Senam Kaki & Pre Test & 15 & 0,9633 & 0,0726 & 0,12122 & 0,03130 & \\
& Post Test & 15 & 1,0360 & & 0,10084 & 0,02604 & \\
\hline
\end{tabular}

Sumber : Data Penelitian 2018

Berdasarkan tabel 4 didapatkan hasil pada kelompok senam kaki rata-rata nilai ABI sebelum perlakuan adalah 0,9633 ( $S D=0,12122)$. Sedangkan rata-rata nilai $A B I$ sesudah perlakuan adalah 1,0360 ( $\mathrm{SD}=0,10084$ ). Hasil statistik uji $\mathrm{T}$ berpasangan (paired t-test) untuk nilai Ankle Brachial index (ABI) didapatkan nilai $p=0,041$ $(p<0,05)$ maka dapat ditarik kesimpulan a) secara statistik nilai ABI sebelum diberikan perlakuan senam kaki berbeda dengan nilai ABI sesudah diberikan senam kaki ; b) ada perbedaan yang signifikan antara nilai $\mathrm{ABI}$ sebelum dan sesudah diberikan perlakuan senam kaki. Berdasarkan hasil dari kedua kelompok pengukuran dapat ditarik kesimpulan bahwa intervensi buerger allen exercise dan senam kaki sama-sama efektif untuk meningkatkan nilai ABI pada pasien diabetes mellitus tipe II namun pada kelompok buerger allen exercise memiliki selisih rata-rata nilai ABI lebih tinggi daripada kelompok senam kaki yaitu selisih rata-rata nilai ABI pada kelompok buerger allen exercise sebesar 0,0820 sedangkan selisih rata-rata nilai ABI pada kelompok senam kaki sebesar 0,0726.

\section{PEMBAHASAN}

\section{Karakteristik Responden}

Usia responden minimal dari kedua kelompok yaitu 45 tahun dan maksimal 71 tahun. Jadi dapat ditarik kesimpulan bahwa usia responden dari kedua kelompok adalah usia tua. Menurut ACCF/AHA (2011) usia tua adalah faktor resiko utama seseorang menderita PAP (sebuah kondisi penyempitan pembuluh darah arteri yang menyebabkan aliran darah menjadi terganggu terutama kearah tungkai bawah). Resiko PAP meningkat seiring dengan bertambahnya usia, dari 3\% pada pasien $<60$ tahun hingga $20 \%$ pada usia $>75$ tahun dan didapati pula pada pasien usia $\leq 50$ tahun, tetapi jumlah kasusnya sangat kecil. Hubungan usia dan PAP mencerminkan lebih panjangnya lama paparan terhadap faktor-faktor aterogenik disertai efek-efek kumulatif penuaan pada pembuluh darah. Proses penuaan secara alami menyebabkan pembuluh darah pada usia tua lebih rentan mengalami aterosklerosis sehingga menyebabkan gangguan pada sirkulasi perifer. Sel-sel radang, sel endotel dan sel otot polos pembuluh darah pada usia tua berbeda dibandingkan sel-sel pada usia muda (Wang et al., 2012). Hal ini didukung oleh penelitian Simatupang (2013) didapatkan hasil bahwa orang dengan usia yang lebih tua berisiko 1,881 kali untuk menderita PAP.

Penuaan menyebabkan perubahan dalam potensi proliferasi sel, proses apoptosis dan kerusakan DNA. Jumlah NO dan respon vaskular terhadap NO menurun seiring bertambahnya usia. Penurunan NO menyebabkan gangguan relaksasi pada pembuluh darah (Thendria, 2014). Sel endotel dan sel otot pembuluh darah pada usia tua mensekresi sitokin proinflamasi yang menyebabkan inflamasi persisten pada pembuluh darah. Lapisan intima dan media pembuluh darah pada proses penuaan terus mengalami 
remodeling berupa peningkatan deposisi kolagen dan degenerasi elastin sehingga pembuluh darah kehilangan elastisitasnya dan menjadi kaku (Wang et al., 2012). Akibatnya sirkulasi darah ke perifer akan terganggu. Menurut Smeltzer \& Bare (2008) proses penuaan mengakibatkan perubahan di dinding pembuluh darah sehingga mempengaruhi transportasi oksigen dan nutrisi ke jaringan. Lapisan intima menebal sebagai akibat proliferasi seluler dan fibrosis. Serabut dilapisan media mengalami kalsifikasi, tipis, dan terpotong, serta kolagen yang menumpuk dilapisan intima dan media. Perubahan tersebut menyebabkan kekakuan pembuluh perifer, dan gangguan aliran darah. Akibatnya akan berpengaruh terhadap nilai ABI sebagai indikator adanya gangguan vaskularisasi perifer.

Jenis kelamin responden penderita diabetes mellitus tipe II terbanyak pada penelitian ini yaitu kelompok buerger allen exercise dan senam kaki adalah laki-laki masing-masing sebanyak $8(53,3 \%)$. Sedangkan jenis kelamin perempuan pada kedua kelompok masing-masing sebanyak $7(46,7 \%)$. Jenis kelamin juga dapat berpengaruh terhadap vaskularisasi perifer. Pada penelitian Thendria (2014) Dari 12 subjek yang menderita PAP berdasarkan nilai ABI, 9 orang berjenis kelamin pria (75\%) dan 3 orang berjenis kelamin wanita (25\%).

Jenis kelamin pria merupakan salah satu faktor resiko PAP (AHA, 2011). Pria lebih rentan mengalami proses aterosklerosis dibandingkan wanita. Hormon estrogen pada wanita memiliki vasoprotektif yang mencegah proses aterosklerosis pada wanita. Estrogen mempunyai efek terhadap NO, profil lipid dan efek antiinflamasi. Estrogen mempengaruhi kadar dan aktivitas NO. Wanita memilki respon relaksasi dan vasodilatasi pembuluh darah yang lebih baik dibandingkan pria. Estrogen meningkatkan kerja antioksidan, menurunkan kadar LDL dan meningkatkan kadar HDL, serta memiliki efek anti-inflamasi. Estrogen juga memicu pertumbuhan endotel baru, dan menghambat proliferasi sel otot polos pembuluh darah. Hormon estrogen bekerja menghambat aterogenesis melalui berbagai mekanisme tersebut (Villablanca et al., 2010).

Kelompok senam kaki mempunyai jumlah responden yang mempunyai riwayat merokok lebih tinggi daripada kelompok buerger allen exercise. Hal tersebut dapat mempengaruhi hasil rata-rata peningkatan nilai ABI karena riwayat merokok mempunyai pengaruh terhadap penurunan nilai $\mathrm{ABI}$ dan menandakan adanya gangguan vaskularisasi perifer. Kebiasaan merokok juga merupakan salah satu faktor utama penyebab terjadinya penyakit penyakit arteri perifer. Penyakit arteri perifer biasanya menyumbat arteri yang berukuran sedang hingga besar serta menyerang tungkai kaki pada bagian bawah sehingga dapat meningkatkan insiden terjadinya gangrene pada kaki penderita diabetes mellitus. Radikal bebas dalam rokok akan memicu penurunan fungsi endotel. Akibat penurunan fungsi tersebut, sel-sel inflamasi, trombosit, dan LDL akan mudah melekat ke dinding pembuluh darah sehingga dapat membentuk plak pada pembuluh darah dan menyebabkan aterosklerosis. Apabila paparan radikal bebas terjadi secara terus-menerus akan menyebabkan kerusakan pembuluh darah dan gangguan sirkulasi (Shabira et al., 2014).

Berdasarkan penelitian Sihombing (2008) didapatkan hasil bahwa merokok merupakan faktor resiko penyebab penyakit arteri perifer dengan OR 5,37 kali dengan 95\% CI (1,90-15,32), dan dari 339 total responden didapatkan hasil 12\% responden merokok dan sisanya tidak merokok yaitu masing-masing 3,5\% perokok ringan, 5\% perokok sedang, 3,5\% perokok berat. Persentase responden yang menderita PAP pada perokok ringan sebesar $45 \%$, pada perokok sedang $92 \%$, dan perokok berat $90 \%$, 
sedangkan persentase responden yang menderita PAP namun bukan perokok didapatkan hasil lebih rendah yaitu $39 \%$.

Beberapa kandungan racun berbahaya dalam rokok adalah nikotin, tar, dan karbonmonoksida. Nikotin menyebabkan perangsangan katekolamin (adrenalin) yang bersifat memacu kerja jantung dan tekanan darah yang berakibat timbulnya hipertensi serta penempelan trombosit ke dinding pembuluh darah. Tumpukan ini memicu peradangan sehingga semakin banyak sampah yang menumpuk di dinding pembuluh darah yang berakibat terjadinya penyempitan pembuluh darah (aterosklerosis). Gas karbonmonoksida dalam darah akan mengikat hemoglobin lebih cepat sehingga akan menurunkan penghantaran oksigen ke jaringan seluruh tubuh (Smeltzer \& Bare, 2008). Gas karbonmonoksida akan menganggu pelepasan oksigen, meningkatkan kekentalan darah, dan penggumpalan darah sehingga menyebabkan terjadinya aterosklerosis. Tar merupakan komponen padat asap rokok yang bersifat karsinogen. Endapan padat tar di dalam pembuluh darah dapat menyebabkan kerusakan dinding pembuluh darah dan menyumbat (Aryani et al., 2016). Aterosklerosis mengakibatkan vaskuler insufisiensi sehingga aliran darah ke dorsalis pedis, popliteal, dan tibialis juga akan menurun sehingga akan mempengaruhi nilai $\mathrm{ABI}$ sebagai indikator adanya gangguan vaskularisasi perifer.

Pada penelitian ini riwayat hipertensi juga berpengaruh terhadap nilai ABI. Kelompok senam kaki mempunyai jumlah responden yang mempunyai riwayat hipertensi lebih tinggi daripada kelompok buerger allen exercise. Hal tersebut juga dapat mempengaruhi hasil rata-rata peningkatan nilai $A B I$ karena riwayat hipertensi mempunyai pengaruh terhadap penurunan nilai $\mathrm{ABI}$ dan menandakan adanya gangguan vaskularisasi perifer. Pada penelitian ini tidak di teliti lama waktu responden menderita hipertensi, hanya mengetahui apakah responden mempunyai riwayat hipertensi atau tidak. Hipertensi juga dapat berpengaruh terhadap kejadian penyakit arteri perifer melalui perannya dalam proses terjadinya arteriosklerosis. Hipertensi dapat menyebabkan arteriosklerosis dengan berbagai mekanisme, antara lain disfungsi endotel yang menyebabkan remodelling dinding arteri dan diameter lumen menurun. Abnormalisasi faktor homeostasis yang menyebabkan renin angiotensin aldosteron system menghasilkan ACE dan peningkatan Angiotensin-II, menyebabkan volume darah meningkat, dan vasokonstriksi. Curah jantung dan tahanan perifer tidak seimbang sehingga terjadi peningkatan masa ventrikel dan proliferasi sel otot polos, maka pembuluh darah akan menebal dan tidak elastis. Dari hasil berbagai macam mekanisme di atas merupakan beberapa penyebab terjadinya aterosklerosis (Kusumawardani, 2011).

Tekanan darah yang tinggi juga dapat menyebabkan arteri berdilatasi dan teregang berlebihan sehingga dapat mengakibatkan cedera pada endotel. Disfungsi endotel menyebabkan abnormalitas tonus otot polos pembuluh darah, proliferasi sel otot polos pembuluh darah, gangguan koagulasi dan fibrinolisis serta inflamasi persisten (Aryani et al., 2016). Disfungsi dan kerusakan endotel serta arteriosklerosis akan mengakibatkan gangguan vaskularisasi perifer. Penelitian Thendria (2014) didapatkan hasil prevalensi PAP hipertensi ditemukan sebesar 21\% (IK 95\% 11-31\%) dan sekitar 2-5\% pasien hipertensi memiliki resiko menderita PAP dan 35-55\% pasien dengan PAP diketahui menderita hipertensi. Hal ini didukung oleh penelitian yang dilakukan oleh Simatupang (2013) bahwa terdapat 34 orang $(89,5 \%)$ dengan tekanan darah normal memiliki nilai $\mathrm{ABI}$ normal dan hanya terdapat 4 orang (10,5\%) dengan $\mathrm{ABI}$ tidak normal, sedangkan pada pasien hipertensi terdapat 44 orang $(71,0 \%)$ dengan $A B I$ normal dan 18 orang $(29,0 \%)$ dengan $\mathrm{ABI}$ tidak normal. 
Hasil penelitian menunjukkan bahwa untuk riwayat kolesterol pada kelompok buerger allen exercise dan senam kaki terbanyak adalah tidak memiliki riwayat kolesterol masing-masing sebanyak $9(60 \%)$. Sedangkan responden yang memiliki riwayat kolesterol pada kedua kelompok masing-masing sebanyak 6 (40\%). Pada penderita DM apabila kadar insulin berkurang di dalam darah, maka gula darah tidak bisa diproses menjadi energi akibatnya kadar glukosa darah akan meningkat berlebihan. Glukosa yang meningkat secara berlebihan akan merusak pembuluh darah, karena gula tidak bisa diproses menjadi energi pada penderita DM. Maka energi akan dibuat dari sumber seperti protein dan lemak. Akibatnya, kolesterol yang terbentuk di metabolisme lemak akan menumpuk dan mengancam pembuluh darah. Pada pasien DM Tipe II, endapan lemak akan disimpan di dinding sel dan akan mengurangi jumlah reseptor insulin sedangkan reseptor insulin sel tidak mampu menangkap gula dan mengakibatkan glukosa darah menjadi tinggi. Dislipidemia didefinisikan sebagai kelainan metabolisme lipid dimana terjadi peningkatan maupun penurunan komponen lipid dalam darah. Kelainan komponen lipid yang utama adalah terjadinya kenaikan kadar kolesterol total, kolesterol LDL (low Density Lipoprotein), TG (trigliserida), serta menurunnya kolesterol HDL (High Density Lipoprotein) (Black \& Hawks, 2014).

Peningkatan kolesterol total, kolesterol LDL, kolesterol very low density lipoprotein (VLDL), dan trigliserida merupakan faktor risiko independen terjadinya PAP, walaupun kadar LDL tidak selalu meningkat, tetapi partikel LDL akan mengalami penyesuaian perubahan (modifikasi) menjadi bentuk kecil dan padat yang bersifat aterogenik yang dapat menyebabkan ateroskerosis dan menghambat fungsi endotel dalam vasodilatasi (Simatupang, 2013). Menurut penelitian Aryani (2016) menunjukkan hasil bahwa dari 30 responden didapatkan 12 orang positif PAP $(40,0 \%)$ dengan nilai $\mathrm{ABI}<0,9$ dan 18 orang normal $(60 \%)$. Pasien dengan PAP positif memiliki rerata kadar kolesterol total 212,0 ( $\mathrm{SB}=45,8)$; rerata kadar LDL 136,83 (SB=31,01); rerata kadar HDL 25,58 ( $\mathrm{SB}=9,55)$; dan kadar trigliserid dengan rentang 114-653. Pasien yang tidak terdiagnosis PAP memiliki rerata kadar kolesterol total 164,33 $(\mathrm{SB}=34,08)$; rerata kadar LDL 104,44 (SB=30,56); rerata kadar HDL 33,67 (SB=5,07); dan kadar trigliserid dengan rentang 60 - 264. Hal ini menunjukkan pasien dengan PAP memiliki kadar kolesterol total, LDL dan trigliserid yang lebih tinggi dibanding pasien yang tidak terdiagnosis PAP dan terdapat hubungan yang bermakna antara dislipidemia dengan status PAP. Asam lemak bebas yang berlebih dan resistensi insulin yang menyebabkan meningkatnya stress oksidatif, menurunnya nitrit oxide (NO), meningkatnya endhotelin-1, meningkatnya angiotensin II, aktivasi platelet, dan berkurangnya fibrinolisis yang mana semua ini menyebabkan disfungsi endotel.

Lama menderita DM responden minimal dari kedua kelompok yaitu 2 tahun dan maksimal 20 tahun. Lamanya waktu seseorang mengalami DM dapat memperberat resiko komplikasi. Lamanya waktu seseorang mengalami DM dapat memperberat resiko komplikasi diabetes mellitus salah satunya adalah terhambatnya vaskularisasi perifer sehingga dapat menurunkan nilai ABI, dan berakibat pada terjadinya ulkus diabetikum. Peningkatan kadar gula darah yang lama mengakibatkan rusaknya lumen pembuluh darah. Kerusakan lumen pembuluh darah akan mempengaruhi sirkulasi perifer. Hiperglikemia dalam waktu yang cukup lama akan menyebabkan terjadinya penumpukan kadar glukosa pada sel dan jaringan tertentu yang kemudian dirubah menjadi sorbitol yang merupakan penyebab kerusakan dan perubahan fungsi sel. Sorbitol bermetabolisme lambat, kemudian ditambah terbentuknya Advanced Glycation End Products (AGEs). AGEs berupa zat yang tidak dapat dimetabolisme lebih lanjut 
sehingga terakumulasi di dinding pembuluh darah dan menyebabkan aterosklerosis yang menyebabkan gangguan vaskuler sehingga sikulasi perifer terganggu (Black \& Hawks, 2014).

Diabetes mellitus juga dapat mengganggu fungsi lapisan endotel di arteri. Lapisan ini merupakan organ yang aktif secara biologi, yang berfungsi memproduksi zat vasodilator yang dinamakan endothelium derived relaxing factors (EDRF) yang dikenal juga sebagai Nitric Oxide (NO). NO adalah stimulus yang penting dari vasodilatasi dan mengurangi terjadinya peradangan melalui modulasi interaksi leukosit dan dinding pembuluh darah dan lebih jauh NO membatasi migrasi dan proliferasi vascular smooth muscle cell (VSMC) serta membatasi aktivasi dari sel pembekuan darah. Inilah sebabnya, hilangnya NO akan mengganggu pembuluh darah yang menyebabkan aterosklerosis (Sihombing, 2008). Oleh karena itu, Peningkatan komplikasi vaskular pada penderita diabetes bergantung pada lamanya menderita penyakit dan bagaimana kontrol gula darah mereka Semakin lama seseorang menderita DM, maka resiko terjadinya aterosklerosis semakin meningkat dan kecenderungan nilai ABI akan menurun. Berdasarkan hasil penelitian Yusra (2010) dapat disimpulkan bahwa rata-rata lama menderita DM pada klien DM Tipe II yang berkunjung kepoliklinik penyakit dalam berkisar antara 5,3-7,0 tahun. Selain itu, penelitian Suri (2018) lama menderita menderita DM Tipe II yang terbanyak adalah menderita diabetes di atas 10 tahun $(47,5 \%)$ dan paling sedikit menderita di bawah 5 tahun $(22,5 \%)$. Selain itu, Penelitian Simanjuntak (2016) menunjukkan bahwa responden yang menderita DM diatas 10 tahun mempunyai rata-rata nilai $\mathrm{ABI}$ lebih rendah dari responden yang menderita $\mathrm{DM}$ kurang dari 10 tahun.

\section{Perbedaan Nilai Ankle Brachial Index (ABI) Sebelum dan Sesudah Perlakuan pada Kelompok Buerger Allen Exercise}

Buerger allen exercise merupakan kombinasi antara perubahan postural (elevasi kaki $45^{\circ}$, penurunan kaki, dan tidur terlentang) serta muscle pump pada bagian ankle yang terdiri dari dua gerakan yaitu dorsofleksi dan plantarfleksi (Chang et al., 2015). Elevasi kaki $45^{\circ}$ merupakan pengaturan posisi dimana anggota gerak bagian bawah diatur pada posisi lebih tinggi dari pada jantung. Kondisi tersebut merupakan suatu upaya untuk membuat suatu perbedaan tekanan antara ujung kaki dan jantung. Darah dalam pembuluh darah bersifat seperti cairan yang mengalir dari tempat yang lebih tinggi ke tempat yang lebih rendah sehingga apabila kaki di elevasikan akan terjadi peningkatan aliran balik vena dari ujung kaki atau tungkai bawah menuju jantung sedangkan aliran darah arteri yang akan didistribusikan ke tungkai bawah tekanannya akan berkurang dan alirannya melambat (Guyton, 2012). Memposisikan kaki elevasi akan menyebabkan pengosongan aliran darah di dalam pembuluh darah pada tungkai bawah Selain itu, apabila jumlah darah yang mengalir ke jantung meningkat maka akan menyebabkan dinding ruang jantung meregang sehingga otot berkontraksi lebih kuat lagi, oleh karena itu semua penambahan darah yang kembali kejantung akan di pompa masuk lagi ke sirkulasi secara otomatis. Pada saat proses penurunan kaki dan kaki menjuntai kebawah lebih rendah daripada jantung maka darah yang dibawa oleh pembuluh darah arteri akan mengalir dengan cepat dari tekanan tinggi ke rendah yaitu dari jantung ke tungkai bawah dan akan mengisi aliran di dalam pembuluh darah sehingga aliran darah ke ujung-ujung kaki atau tungkai bawah akan meningkat. Melakukan perubahan gravitasi akan mempengaruhi pendistribusian cairan dalam tubuh dengan cara membantu secara bergantian untuk mengosongkan dan mengisi kolom 
darah, yang dapat meningkatkan transportasi darah melalui pembuluh darah Setelah itu posisi terlentang merupakan posisi yang mensejajarkan tubuh, berperan penting dalam keseimbangan sirkulasi darah (Sherwood, 2016).

Muscle pump berupa dorsofleksi dan plantarfleksi secara aktif dengan menggerakkan otot otot rangka secara aktif menyebabkan otot-otot menekan dan merangsang pembuluh darah (Yollanda et al., 2016). Dorsofleksi adalah gerakan menggerakkan telapak kaki kearah tubuh pada bagian atas sedangkan plantarfleksi adalah menggerakkan telapak kaki kearah bagian bawah sehingga merangsang endotel pembuluh darah untuk mengeluarkan atau melepaskan Nitrit Oksida yang berperan dalam vasodilatasi pembuluh darah yaitu NO (Nitrit Oksida). Nitrit Oksida diproduksi melalui perubahan asam amino L-arginine menjadi L-citrulline oleh enzim NO-synthase (NOS). Nitrit Oksida akan menstimulasi soluble guanilate cyclase (SGC) yang menyebabkan peningkatan sintesa siklik GMP dari guanosin triphosphate (GTP) (Isral, 2014). Peningkatan siklik GMP ini akan menyebabkan otot polos pembuluh darah tersebut relaksasi. Pada saat sel otot-otot polos relaksasi maka pembuluh darah akan vasodilatasi sehingga aliran darah ke perifer kaki menjadi lancar (Purnawarman \& Nurkholis, 2014) .

Penelitian tentang buerger allen exercise yang dilakukan oleh Jemcy (2015) di Chennai India pada 30 penderita DM Tipe II disimpulkan bahwa Buerger Allen Exercise diberikan 2 kali sehari dengan waktu 6 menit dalam kurun waktu 5 hari dapat meningkatkan perfusi ekstremitas bawah atau meningkatkan nilai Ankle brachial index (ABI) dengan rata-rata pretest 0,9220 dan rata-rata posttest 0,9800 , selisih rata-rata nilai ABI sebesar 0,058 didapatkan taraf signifikan $p=<0,05$.

\section{Perbedaan Nilai Ankle Brachial Index (ABI) Sebelum dan Sesudah Perlakuan pada Kelompok Senam Kaki}

Latihan senam kaki yang merupakan sekumpulan gerakan yang salah satunya dorsofleksi dan plantarfleksi serta masih banyak lagi gerakan yang lainnya juga mempunyai efek yang sama yaitu merangsang sel endotel pembuluh darah. Senam kaki yang dilakukan dengan cara menggerakan sendi dan pergelangan kaki akan membuat otot-otot akan secara aktif melakukan pergerakan. Menggerakkan otot otot rangka secara aktif menyebabkan otot-otot menekan pembuluh darah (Yollanda et al., 2016) sehingga merangsang endotel pembuluh darah untuk mengeluarkan atau melepaskan Nitrit Oksida. yang berperan dalam vasodilatasi pembuluh darah yaitu NO (Nitrit Oksida) (Sherwood, 2016).

Penelitian terkait senam kaki juga menunjukkan hasil yang signifikan terhadap nilai ABI yaitu penelitian Tomy (2016) didapatkan hasil bahwa senam kaki yang diberikan $1 \mathrm{kali} /$ hari selama 5 hari terdapat pengaruh yang signifikan terhadap nilai ABI pada kedua kaki dengan rata-rata pretest kaki kanan 0,98 dan rata-rata posttest 1,09 , selisih rata-rata ABI kaki kanan sebesar 0,11. Rata-rata pretest kaki kiri 0,98 dan ratarata posttest 1,06 selisih rata-rata nilai ABI kaki kiri sebesar 0,08. Didapatkan taraf signifikan $p=0,000$. Penelitian Wahyuni et al., (2016) menunjukkan senam kaki yang dilakukan selama 30 menit perhari dalam waktu 3 hari menunjukkan hasil adanya pengaruh yang signifikan terhadap nilai $\mathrm{ABI}$ dengan rata-rata nilai $\mathrm{ABI}$ pretest yaitu 0,62 dan posttest 0,93 , selisih rata-rata nilai ABI sebesar 0,31 , didapatkan taraf signifikan $p=0,005$. Penelitian tersebut didukung juga oleh hasil penelitian Zukhri (2016) bahwa senam kaki dilakukan 2 kali/hari selama 1 bulan juga menunjukkan hasil bahwa terdapat pengaruh yang signifikan terhadap nilai $\mathrm{ABI}$ dengan rata-rata nilai $\mathrm{ABI}$ 
pretest 0,800 dan posttest 1,005 , selisih rata-rata nilai $\mathrm{ABI}$ sebesar 0,205 didapatkan taraf signifikan $p=0,000$.

\section{Perbandingan Hasil Nilai Ankle Brachial Index (ABI) Sebelum dan Sesudah Perlakuan pada Kedua Kelompok Intervensi}

Berdasarkan hasil dari kedua kelompok pengukuran dapat ditarik kesimpulan bahwa intervensi buerger allen exercise dan senam kaki sama-sama efektif untuk meningkatkan nilai ABI pada pasien diabetes mellitus tipe II. Menurut analisis peneliti buerger allen exercise dan senam kaki dapat menjadi latihan mandiri sebagai upaya pencegahan maupun rehabilitasi bagi pasien DM Tipe II yang memiliki resiko menderita gangguan vaskularisasi perifer tungkai bawah. Namun, buerger allen exercise lebih efektif dalam meningkatkan nilai abi daripada senam kaki. Pada kelompok buerger allen exercise memiliki selisih rata-rata nilai ABI lebih tinggi daripada kelompok senam kaki yaitu selisih rata-rata nilai ABI pada kelompok buerger allen exercise sebesar 0,0820 sedangkan selisih rata-rata nilai ABI pada kelompok senam kaki sebesar 0,0726 sesuai dengan data yang didapatkan saat penelitian.

Buerger allen exercise terbukti dapat meningkatkan nilai $\mathrm{ABI}$ lebih tinggi karena adanya perbedaan mekanisme dari perlakuan yang diberikan dimana buerger allen exercise merupakan latihan gabungan dari muscle pump (dorsofleksi dan plantarfleksi) dan perubahan gravitasi (elevasi kaki $45^{\circ}$, penurunan kaki, tidur terlentang) sedangkan senam kaki hanya dilakukan dengan menggerakan sendi dan pergelangan kaki yang membuat otot-otot akan secara aktif melakukan pergerakan menekan pembuluh darah sehingga dapat merangsang endotel untuk vasodilatasi pembuluh darah. Selain itu, dapat disebabkan juga karena adanya perbedaan karakteristik pada kelompok senam kaki berbeda dengan kelompok buerger allen exercise dimana responden pada kelompok senam kaki memiliki rata-rata usia, riwayat merokok, riwayat hipertensi, dan lama menderita DM lebih tinggi dibandingkan pada kelompok buerger allen exercise.

\section{SIMPULAN}

Rata-rata usia responden yaitu 60 tahun, jenis kelamin terbanyak yaitu laki-laki, mempunyai riwayat merokok, hipertensi, dan kolesterol serta mempunyai riwayat lama menderita DM minimal 2 tahun dan maksimal 20 tahun. Terdapat perbedaan nilai Ankle Brachial Index (ABI) yang bermakna pada kelompok buerger allen exercise sebelum dan sesudah dilakukan intervensi. Terdapat perbedaan nilai Ankle Brachial Index (ABI) yang bermakna pada kelompok senam kaki sebelum dan sesudah dilakukan intervensi.

Ada perbedaan selisih nilai Ankle Brachial Index (ABI) pada kelompok buerger allen exercise dan kelompok senam kaki. Buerger allen exercise dan senam kaki samasama efektif dalam meningkatkan nilai Ankle Brachial Index (ABI) namun buerger allen exercise lebih efektif daripada senam kaki karena perbedaan selisih rata-rata peningkatan nilai ABI pada kelompok buerger allen exercise lebih tinggi daripada kelompok senam kaki.

\section{SARAN}

Latihan buerger allen exercise dan senam kaki dapat dijadikan salah satu intervensi keperawatan mandiri pada penderita Diabetes Mellitus Tipe II sebagai tindakan pencegahan gangguan sirkulasi darah perifer kaki dan dapat dijadikan standar operasional prosedur dalam penatalaksanaan asuhan keperawatan klien diabetes mellitus tipe ii dengan gangguan vaskularisasi perifer seperti penyakit arteri perifer yang banyak 
menyerang tungkai bagian bawah.

Selain itu, untuk diruang rawat inap lebih disarankan dilakukan buerger allen exercise daripada senam kaki karena buerger allen exercise lebih mudah untuk dilakukan dan tidak membuat pasien merasa lelah dalam melakukan latihan tersebut karena pasien diabetes mellitus tipe II yang dirawat inap tidak hanya menderita diabetes mellitus saja tetapi mempunyai komplikasi penyakit yang lain.

Latihan buerger allen exercise dan senam kaki dapat dipertimbangkan sebagai evidence based practice untuk dijadikan materi yang diajarkan kepada para mahasiswa. Hasil penelitian ini diharapkan dapat dijadikan sumber ilmu atau referensi baru bagi para pendidik dan mahasiswa sehingga dapat menambah wawasan yang lebih luas dalam hal intervensi keperawatan mandiri.

\section{DAFTAR PUSTAKA}

Aalaa, M., Malazy, O. T., Sanjari, M., Peimani, M., \& Tehrani, M. (2012). Nurses' Role in Diabetic Foot Prevention and Care. A Review Journal of Diabetes \& Metabolic Disorders, 11, 24

Abishal, A. (2016). A Study to Elevated the Effectiveness of Buerger Allen Exercise in Improving Peripheral Circulation Among Diabetes Mellitus Patients in Selected Hospital at Kanyakumari Dictrict

American Heart Association. (2012). Measurement and Interpretation of the AnkleBrachial Index A Scientific Statement from the American Heart Association. http:// ahajournal.org.com. Di akses 02 Maret 2018

American Heart Association. (2011). Management of Patients with Peripheral Artery Disease (Lower Extremity, Renal, Mesenteric and Abdominal Aortic). http:// ahajournal.org.com. Di akses 19 Juli 2018

Aryani, E., Nugroho, H., \& Mangawati, A., (2016) . Hubungan antara Dislipidemia dengan Status Penyakit Arteri Perifer (PAP) pada Pasien Diabetes Melitus Tipe 2 Terkontrol Sedang, 5 (4). http://ejournal-sl.undip.ac.id/index.php/medico. Diakses 07 Maret 2018.

Black, J. M., \& Hawks, J. H. (2014). Keperawatan Medikal Bedah: Manajemen Klinis untuk Hasil yang Diharapkan. Alih Bahasa Edisi 8. Jakarta: Salemba Medika

Chang, C., Chang, C., \& Chen, M. (2015). Effect of Buerger' s Exercises on Improving Peripheral Circulation: A Systematic Review, 120-128

Damayanti, S. (2015). Diabetes Melitus \& Penatalaksanaan Keperawatan. Yogyakarta: Nuha Medika

Guyton, A. C., \& Hall, J. E. (2012). Buku Ajar Fisiologi Kedokteran. Edisi 11. Jakarta: Penerbit Buku Kedokteran EGC

IDF. (2015). IDF Diabetes Atlas Sixth Edition. https://www.idf.org/sites/default/files/Atlas-poster 2015_EN.pdf.s. Diakes 25 Februari 2018

Iraj, B., Khorvash, R., Ebneshahid, A., \& Askari, G. (2013). Prevention of Diabetic Foot Ulcer . International Journal Of Preventive Medicine, 4(3), 373-376. Diakses 07 Maret 2018

Isral, G. N., \& Sulastri, D. (2014). Hubungan Aktivitas Fisik dengan Kadar Nitric Oxide ( NO ) Plasma pada Masyarakat di Kota Padang. Jurnal Kesehatan Andalas, 3(2), 173-177 
Jemcy, J., \& Rathiga, A. (2015). Effectiveness of Buerger Allen Exercise to Improve the Lower Extremity Perfusion among Patients with Type 2 Diabetes Mellitus International Journal of Current Research and Academic Review, 3(4), 358-366

Kohlman, K., \& Tribogof, T. (2013). Management of Lower Extremity Peripheral Arterial Disease: Interpreting the Latest Guidelines for Nurse Practitioners. The Journal for Nurse Practitioner-JNP, 9(10), 653-660

Kusumawardani, R. P. (2011). Konstribusi Hipertensi terhadap Aterosklerosis Arteri Karotis Interna pada Pasien Pasca Stroke Iskemik. Tesis Universitas Diponegoro

Leone, S., Pascale, R., Vitale, M., Esposito, S., (2012). Epidemiology of Diabetic Foot. Infez Med, 20(1), 8-13. https://www.ncbi.nlm.nih.gov/pubmed/22982692. Diakses 07 Maret 2018

Mangiwa I., \& Katuk, M. (2017). Pengaruh Senam Kaki Diabetes terhadap Nilai Ankle Brachial Index pada Pasien Diabetes Melitus. Ejournal Keperawatan (E-Kp), 5(1)

Perkeni. (2015). Pengelolaan dan Pencegahan Diabetes Melitus Tipe 2 di Indonesia. Jakarta : PB Perkeni

Priya, N. (2016). Effectiveness of Buerger Allen Exercise on Levels of Lower Extremity Perfusion among Patients with Selected Non Communicable Diseases Ncds Admitted at Sri Narayani Hospital and Research Centre. Vellore

Purnawarman, A., \& Nurkhalis, N. (2014). Pengaruh Latihan Fisik terhadap Fungsi Endotel. Jurnal Kedokteran Universitas Syiah Kuala, 14(2). Diakses 07 Maret 2018

Rebolledo, F. A., Soto, J. M. T., \& Pena, J. E. (2011). The Pathogenesis of the Diabetic Foot Ulcer: Prevention and Management. http : //www. Intechopen.com/books/global-perspective-on-diabetic-foot-ulcerations. Diakses 10 Maret 2018

Riset Kesehatan Dasar (Riskesdas). (2013). Badan Penelitian dan Pengembangan. Kesehatan Kementerian RI tahun 2013. Diakses 25 Februari 2018. http://www.depkes.go.id/resources/download/general/Hasil\%20Riskesdas\%20

Setiati, S. (2015). Buku Ajar Ilmu Penyakit Dalam. Jakarta: Interna Publishing

Shabira, D., Harjono,Y., \& Bustamam, N. (2014). Hubungan antara Derajat Merokok dan Kadar Gula Darah terhadap Resiko Terjadinya Kaki Diabetic pada Pasien Diabetes Mellitus Pria di RSUD Ciawi Bogor. Jurnal Bina Widya, 25(4), 162-167

Sherwood, L. (2016.) Fisiologi Manusia: Dari Sel ke Sistem Edisi 8. Jakarta: Buku Kedokteran EGC

Sihombing, B. (2008). Prevalensi Penyakit Arteri Perifer pada Populasi Penyakit Diabetes Mellitus di Puskesmas Kota Medan. FK. USU. http://repository.usu.ac.id/bitstream/123456789/633/1/08E00385.pdf. Diakses 18 Juli 2018

Sihombing, D., Nursiswati, N., \& Prawesti, A. (2012). Gambaran Perawatan Kaki dan Sensasi Sensorik Kaki pada Pasien Diabetes Melitus Tipe 2 di. Poliklinik DM RSUD. http:/ /journals. unpad.ac.id/ ejournal/arti cle/view/677Diakses 27 Februari 2018

Simanjuntak, G. V. (2016). Perubahan Ankle Brachial Index akibat Merokok dan Lamanya Menderita Diabetes Melitus Tipe II. Idea Nursing Journal, VII(2) 2016

Simatupang, M., Pandelaki, K \& Panda, L. (2013). Hubungan antara Penyakit Arteri Perifer dengan Faktor Resiko Kardiovaskuler. Jurnal e-Clinic (Eci), 1 (1): 7-12. http://download.portalgaruda.org/article.php?article=14965\&val=1001. Diakses 18 Juli 2018 
Singh, S., \& Dinker, R. (2013). Diabetic Foot Ulcer - Diagnosis and Management. Clinical Research on Foot \& Ankle, 1(3), 1-9. https://doi.org/10.4172/2329910X.1000120

Smeltzer, S., \& Bare, B. G. (2008). Brunner \& Suddarth's Textbook of Medical Surgical Nursing $\left(12^{\text {th }}\right.$ ed). USA: Elsevier Inc

Suri, A. A. L. (2018). Hubungan antara Lama Menderita Diabetes Melitus Tipe 2 dengan Kejadian Peripheral Arterial Disease (PAD) pada Pasien Diabetes Melitus Tipe 2 di Puskesmas Kedaton Kota Bandar Lampung. Skripsi: Universitas Lampung

Thendria, T., Toruan, I. L., \& Natalia, D. (2014). Hubungan antara Hipertensi dan Penyakit Arteri Perifer Berdasarkan Nilai Ankle-Brachial Index. eJournal Kedokteran Indonesia, 2(1), 37-44

Tomy, I. S., \& Righo, A. (2016). Pengaruh Senam Kaki terhadap Perubahan Ankle Brachial Index pada Pasien Diabetes Melitus di Wilayah Kerja Puskesmas Purnama. Naskah publikasi: Universitas Tanjungpura

Villablanca, A. C., Muthuvel, J., Carole, B. (2010). Atherosclerosis and Sex Hormone: Current Concept. Clinical Science. 119, 493-513

Wahyuni, A., \& Arisfa, N. ( 2016). Senam Kaki Diabetik Efektif Meningkatkan Ankle Brachial Index Pasien Diabetes Melitus Tipe 2. Jurnal Ipteks Terapan Research of Applied Science and Education, 9 (I2), 155-164

Wahyuni, T. D. (2013). Ankle Brachial Index (ABI) Sesudah Senam Kaki Diabetes pada Penderita Diabetes Mellitus Tipe 2. Jurnal Keperawatan, 4(2). http://ejournalumm.ac.id/index.php/keperawatan/article/view/2365. Diakses 02 Maret 2018

Wang, J. C., \& Bennett, M. (2012). Aging and Atherosclerosis Mechanisms, Functional Consequences, and Potential Therapeutics for Cellular Senescence. https://doi.org/10.1161/CIRCRESAHA.111.261388

Williams, W., \& Wilkins, W. (2012). Ankle Brachial Index: Quick Reference Guide for Clinicans. Journals Wound Ostomy Continence Nurse, 39(2S), S21-S29

Yollanda, A., \& Widayati, N. (2016). Pengaruh Therapeutic Exercise Walking terhadap Sirkulasi Darah Perifer pada Pasien Diabetes Melitus Tipe 2 di Kelurahan Gebang Kecamatan Patrang Kabupaten Jember. Circulation in Patients with Type 2 Diabetes Mellitus at Gebang Village of Patrang Sub-Dist, 4(3)

Yusra, A. (2010). Hubungan antara Dukungan Keluarga dengan Kualitas Hidup Pasien DMT2 di Poloklinik Penyakit dalam RSUP Fatmawati Jakarta. FKUI

Zukhri, S. (2016). Pengaruh Senam Kaki terhadap Ankle Brachial Index (ABI) pada Pasien Diabetes Melitus Tipe II. Naskah publikasi: Stikes Muhammadiyah Klaten 